\title{
Living in an Emerging Settlement: the Story of Hopley Farm Settlement, Harare Zimbabwe
}

\author{
Abraham R. Matamanda ${ }^{1}$ \\ Published online: 20 June 2020 \\ C) Springer Nature B.V. 2020
}

\begin{abstract}
A phenomenological research design guided the study that documented the daily lives of citizens living in emerging settlements. Hopley Farm Settlement in Harare, Zimbabwe, was used as a point of reference. The study argued that emerging settlements are neglected spaces in which residents improvise in their daily life activities to enhance the livability of the settlements. The theory of desperation, which puts into perspective issues of spatial (in) justice, exclusion, power, and oppression, formed the theoretical foundation of the study. Findings spotlight some of the dilemmas experienced by residents living in emerging settlements. These citizens experience multiple shocks and stresses, which include lack of basic services, disconnection from formal services and the urban core, political exclusion, and violation of their human rights. In this regard, households engage in various activities that fall between resilience and desperation as they try to navigate their way in claiming the right to the city. The study recommends politicians and the government to put aside political differences and consider the welfare of the people instead of advancing political agendas.
\end{abstract}

Keywords Emerging settlement $\cdot$ Exclusion $\cdot$ Hopley Farm Settlement · Theory of desperation

\section{Introduction}

This study is framed in the context of the Sustainable Development Goals (SDGs) that seeks "to leave no one behind" as the world progresses towards an equitable and inclusive development trajectory (United Nations 2016). The increasing rate of urbanization in cities of the Global South, especially in Africa-with an annual urbanization rate of $4 \%$ (Bafana 2016) - makes it important to examine the living conditions of

Abraham R. Matamanda

matamandaa@gmail.com

1 Department of Urban \& Regional Planning, University of the Free State, Bloemfontein, South Africa 
citizens in emerging settlements as the number of urban dwellers continues to soar each day (Lall et al. 2017). For example, in 2019, 21 million people resided in Lagos, Nigeria, and that population is anticipated to reach 88 million by 2100 (Obasanjo et al. 2020). Yet, close to a million of the present urban dwellers in Lagos live under appalling conditions akin to "the city of dreadful night" (Hall 1996) that characterized cities during the industrial revolution in Europe. During the industrial revolution, water and sanitation services were absent and citizens lived in crowded makeshift dwellings that left them vulnerable to public health risks (Corburn 2013). As the urban population increases, so does the proliferation of emerging (informal) settlements to accommodate the burgeoning urban population, especially the poor. Emerging settlements start from scratch, often situated on the edge of cities where they accommodate poor households who live in locations where land values are relatively low owing to the absence of bulk municipal services (Green and Handley 2009). Yiftachel (2009) postulates that emerging settlements are gray spaces that arise when people are indefinitely positioned between the "lightness" of legality, safety, and full membership, and the "darkness" of eviction, destruction, and death. According to Lall et al. (2017, p. 64), emerging settlements exist on the margins of formality and informality, which in most cases, results from sprawling development beyond the administrative boundary of the city or beyond the city edge where the council can provide basic services. Emerging settlements tend to be situated on the city edge where land values are relatively cheap due to the absence of the public services. In this way, people increase their disposal incomes by saving on housing costs and compromise by not having basic amenities. Chatiza (2013) opines that elites establish emerging settlements who allocate undeveloped land to the homeless citizens, usually under their political banner. Beyond the allocation of such land, politicians will do nothing else and leave the communities in a state of desperation where they are promised services, which are never delivered. In African cities, citizens living in emerging communities suffer the most as they tend to be marginalized and disconnected from the "formal city," yet they are a part of this urban system (Mphambukeli 2019). Livability of citizens is compromised such that socio-spatial and economic segregation manifests and eventually intensifies. This results in some urbanites being left behind, contrary to the vision of the Sustainable Development Goals and New Urban Agenda aspiring for the creation of livable and inclusive urban communities.

Zimbabwe is no exception and has experienced a rapid rate of urbanization over the past decades with the larger proportion of urban population residing in Harare, the capital city. The proliferation of emerging communities in the city is alarming and residents in such settlements live under harsh conditions. The main challenge is that the government tends to overlook the needs of these communities and rather displaces, evicts, or destroys the settlements as and when they feel fit (Potts 2007; Huchzermeyer 2011). The daily lives of residents in emerging settlements remains masked and overlooked and it becomes difficult to integrate their concerns into urban policy and development. Yet, there is a need to understand the daily experiences of these communities to formulate regeneration programs that may spur sustainable, safe, and inclusive settlements. Among these settlements is Hopley Farm Settlement (hereafter referred to as Hopley) in Harare, Zimbabwe. The persistence of urban challenges in emerging communities makes it difficult to attain inclusive, resilient, sustainable, and safe communities. This situation may have catastrophic effects on the socioeconomic, 
political, and environmental situation of Harare and Zimbabwe, as conflicts arise between the haves and the haves nots. Communities become vulnerable to disease outbreaks such as endemic cholera and the novel coronavirus. Additionally, impacts of natural disasters tend to be exacerbated in poor communities.

Hopley is used as a case study because it is an emerging settlement that was established by the Government of Zimbabwe in 2005 following Operation Murambatsvina $^{1}(\mathrm{OM})$. Fifteen years later, the settlement is still evolving, but is largely contested and characterized by lack of basic services. The history of Hopley is characterized by displacement of households, evictions, and intimidation, which makes it a good example for exploring the lived experiences of residents in emerging settlements. The study asks a critical question relating to the livability of Hopley and how the residents experience their daily lives and attempt to make their communities livable. The study determines the rights of Hopley citizens to the space and whether they have control over their space. This brings to attention key insights with regard to urban spaces and how the poor navigate their territories and try to make a living. The study presents a review of literature on marginalization, exclusion, and emerging settlements. This is buttressed by a theoretical framework that explores the theory of desperation. The qualitative design for the study is explained followed by the presentation of the findings, discussion, and conclusion.

\section{Theory of Desperation}

Mtapuri and Myeni (2020) argue that poor people are forced out of desperation to construct their own dwellings using any materials and skills they have, but end up residing in communities and circumstances that make them susceptible to socioecological risks. This sentiment is made by individuals and groups claiming their right to the city (Harvey 2012). Turok (2020) asserts that cities fail to anticipate and plan for the population influx, and risk falling so far behind in service delivery, making it impossible to catch up with people's need for basic services. Mtapuri and Myeni (2020) identify four spaces occupied by the poor claiming their right to the city. First, are spaces of both comfort and discomfort where the former is offered by the dwellings, while the latter comes from the external elements that compromise the livability in the dwelling. Even though residents in settlements like Kibera and Mukuru slums in Nairobi have the "comfort" of a roof over their head, they are still confronted with daily risks and hazards such as disease outbreaks, violence, flooding, constant threat to their livelihoods, and fear of eviction and displacement (Wanjiru and Matsubara 2017; Fahlberg et al. 2020).

Second, the spaces perpetuate oppression and domination. The everyday life of residents is characterized by an allegiance to individuals and groups possessing authority or power over the land on which the settlements are established. The rights of the residents in the settlements are often ignored and they remain vulnerable to the actions and decisions of those in power to decide their fate. Oppression is rife as the residents

\footnotetext{
${ }^{1}$ In 2005, the Government of Zimbabwe launched Operation Murambatsvina (Remove filth) as part of a blitz that sought to remove all the urban informal activities and structures on the pretext of cleaning the urban areas that were increasingly concentrated with informal activities, structures, and businesses.
} 
are denied opportunities like any other citizen. Their rights to housing and privacy are threatened and contravened mainly through evictions, demolitions, and displacements, as officials seek to eradicate emerging settlements when they are situated on council land (LeVan and Olubowale 2014). Third, the spaces are characterized by restricted choices and constrained opportunities for the residents, which are restricted by regulations and laws, property owners, and authorities (Mtapuri and Myeni 2020). These restrictions include building materials, dwelling size, and location of buildings. The lack of municipal services exposes the poor to a number of risks, especially disease outbreaks. These are spaces of exclusion where the poor are confined and directed to those waiting to become beneficiaries of government housing. These spaces are thus monopolized by the politicians to protect their interests.

\section{Exclusion, Oppression, and Spatial Injustice}

The theory postulated by Mtapuri and Myeni (2020) brings into perspective three key issues that define the everyday lives of citizens in emerging settlements, namely oppression, exclusion, and spatial injustice. According to Young (1990), oppression manifests through exploitation, which is when people in power exercise their control for the purposes and benefit of select individuals. In such instances, human rights tend to be undermined, as the interests of a few are recognized and honored. Marginalization follows as the second strand of oppression through which some people are expelled from useful participation in social life. The result is that such groups and individuals are deprived of certain materials, which include accessing basic services (Young 1990, p. 51). Hall (1996, p. 363-400) describes the marginalized as those occupying the "city of the permanent underclass." Their exposure to poverty is constructed and is a necessary social evil that has to be maintained to keep them loyal to the ruling class. Third is powerlessness, and Mtapuri and Myeni (2020) argue that these are spaces of participatory exclusion. Young (1990, p. 52) asserts that powerlessness manifests among the oppressed who lack the power or authority to determine their fate. They do not have a say in matters that concern them, rather they are subjects whose fate is determine by the elites.

Spatial justice is a recurrent theme in urban planning, as there is an increasing call for establishment of just cities (Fainstein 2014). However, spatial justice is a valueladen concept that is at times misunderstood. Broadly, justice is framed in the context of equity in the distribution of urban services and goods such that there is fairness in the distribution of services with no one being disadvantaged. PhilippopoulosMihalopoulous (2010, p. 189) asserts that, "If spatial justice is simply a just distribution of resources in a given region, one is left wondering whether any justice can possibly afford not being "spatial" in this narrow sense. On the contrary, if the peculiar characteristics of space are to be taken into account, a concept of justice will have to be rethought on a much more fundamental level than that." Here, justice is narrowly viewed because some goods and services cannot be easily distributed or redistributed, hence the need for new approaches to explore justice (Moroni 2019). Power is a critical element that is identified as the cornerstone of spatial justice. Social justice speaks of power in public institutions, hence a need to reconsider the institutional setup and public policy formulation in African cities (Moroni 2019). Instead of planning to eliminate the poor, it is important to plan with the poor and give them a voice so that 
their concerns are integrated in city plans (Johari 2019). The rationale is to eradicate inequality and promote inclusion in accessing services. In emerging human settlements, spatial justice becomes critical, as it affects the daily experiences of the citizens and how they navigate their communities.

\section{Methodology}

A qualitative research design (Creswell 2013) was adopted where survey research and descriptive phenomenology were used. Both secondary and primary data sources were used to collect data. The sample size of the Hopley households was determined so that a confidence level of $95 \%$ was maintained (allowing a margin of error of 5\%), according to Krejcie and Morgan's (1970) sample size table. Since the councilor indicated that the number of households in Hopley was usually under estimated, 450 questionnaires instead of 365 were administered to allow for attrition and enhance the validity of the results by having a statistically representative sample. The questionnaire comprised demographic information, socioeconomic conditions of the residents, their daily experiences in accessing basic services, and the condition of the services they have. These key issues included in the survey enabled me to gain more insight into the daily lives of the residents. The questionnaire was digitized and incorporated a Geographic Positioning System and used during the survey, which was conducted from September to November 2017. The Kobo Data Collector (Olajide 2019) was used because it enabled the digitization of the questionnaire during the data collection process.

Furthermore, 20 household heads were purposively selected for in-depth interviews during the administration of the questionnaires. These respondents were chosen because they showed much interest in the study and were willing to share additional information. Creswell (2013) indicates that small sample sizes are ideal for phenomenological studies; thus, the 20 household heads were sufficient for in-depth interviews. The in-depth interviews were conducted to document the lived experiences of the households with regard to living in Hopley. The interview questions were framed around issues of poverty and morality, housing conditions, oppression, and exclusion. Each interview was approximately $60 \mathrm{~min}$ and were all record with the consent of the participants. Open-ended questions guided the interview to allow participants to elaborate when they had not provided clear responses. Textual analysis was used to analyze the data from the transcriptions. The recordings were transcribed and coded after which themes were identified.

\section{Findings and Discussion}

\section{Background of Hopley Settlement}

Hopley is situated on the edge of the southern parts of Harare (see Fig. 1). It is laden with history of evictions and demolitions linked back to Porta Farm in 1992. The government moved informal settlers from Mbare and Epworth to Porta Farm shortly before commonwealth meeting held in Harare in 1992. As more poor households 
continued to move from Harare to Porta Farm in search of cheaper housing, the government eventually responded by evicting many families from Porta Farm (and Churu Farm) in late 1993 and early 1994 and took them to Hatcliffe Extension (Chitekwe-Biti 2009). Subsequently, in 2005, these families were evicted during OM from Porta Farm and Hatcliffe Extension among many other settlements in Harare. Similar cases of such evictions, displacements, and social injustices are evident in the history of Zimbabwe. For example, in 1983, the Zimbabwe African National Union Patriotic Front (ZANU-PF) initiated "Operation Clean-up" that caused the destruction of viable urban habitats in Harare (Patel 1988, p. 211). In March 2001, demolitions took place where over 500,000 people were left homeless in the Mbare high-density area, after the municipality destroyed over 145,000 "illegal" outbuildings (The Herald, 10 March 2001). The 2005 OM shows a circle of oppression, exclusion, and spatial injustice that has persisted in urban Zimbabwe, especially Harare (Zinyama et al. 1993; Amnesty International 2006). The intervention of the international community and civic organizations showed a disapproval of OM, which saw an estimated 570,000 urban people losing their homes, while 98 lost their informal livelihoods. This eventually compelled the government to launch operation Garikai/Hlalani Kuhle (GHK) as a cover up to accommodate the victims of OM (Potts 2007). Therefore, this history of desperation, power, and intimidation shows how for many years, informal businesses and housing have struggled to exist in Harare due to government's negative attitude towards settlements. It also reveals the vulnerability of the urban poor who lack the capacity to influence decisions that relate to the creation of settlements, which accommodate them (Mtapuri and Myeni 2020).

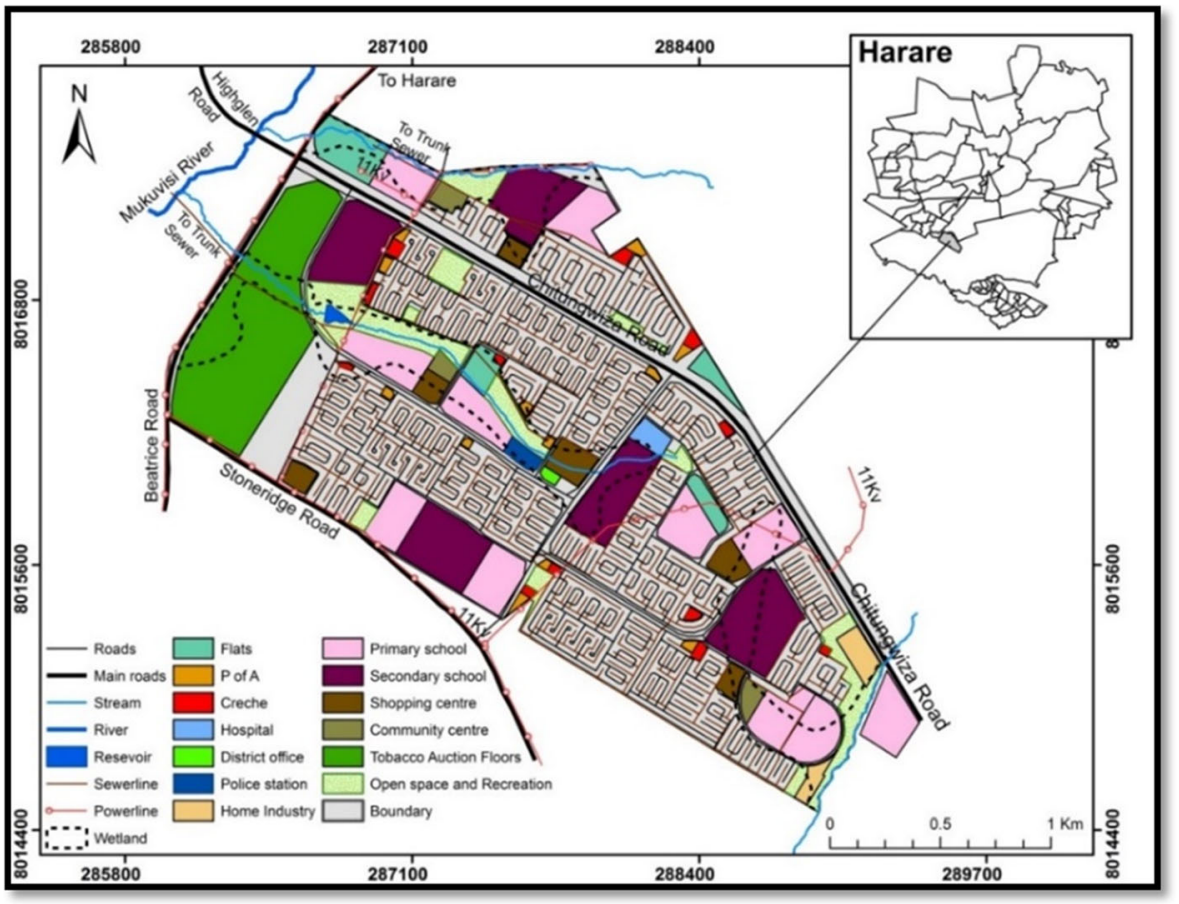

Fig. 1 Layout of Hopley 
Consequently, Hopley was established in 2005 as part of GHK, which was a government response to OM. An official from City of Harare explained, "Through the Southern Areas Incorporated plan, the development of Hopley was envisioned but it remained shelved due to the absence of basic services and public infrastructure in the area. However, following OM, the City of Harare was directed by the government to allocate plots to some victims of the operation." It thus emerges that Hopley was founded on the notion of exclusion and confinement for the poor, mainly displaced from informal settlements and brought to new settlements where their choices and opportunities were constrained, as described by Mtapuri and Myeni (2020). The survey revealed that $26 \%(n=119)$ of the respondents were displaced from Porta Farm during OM and were brought to Hopley under GHK, while 53\% $(n=237)$ indicated that they were displaced from various areas around Harare. Some displaced respondents were beneficiaries on the council's housing waiting list. The remaining $21 \%(n=94)$ were individuals who migrated from other areas outside Harare. "Not everyone here originally came from Porta Farm. When the government brought us from Porta Farm, the formal procedures of allocating us were not followed and this resulted in other homeless people also coming to settle on vacant land."2 Therefore, Hopley has different parts. First is council land that was allocated by City of Harare, which through beneficiaries and cooperatives provided road, water, and sanitation infrastructure for themselves.

Second is the area allocated by government after OM, though planned has service delivery challenges. Third is an informal settlement where people settle willingly. The majority include beneficiaries who obtained the plots through ZANU-PF ${ }^{3}$ as the process at some point was politicized and the council lost its legitimacy in this settlement. The establishment of Hopley relates with the notion of desperation. Victims of forced displacement and government initiated evictions have no choice, but to settle wherever the government allows them to do so, regardless of tenure rights or availability of basic services. The history of the establishment of Hopley riddled with displacement, forced evictions, and intimidation of the poor is similar to what Mtapuri and Myeni (2020) identify as discomfort that comes from the residents' fear of further evictions. Hopley is a complex settlement and is an excellent case study to unpack the theory of desperation, linked to oppression, exclusion, and spatial (in) justice. It is densely populated and synonymous with poverty, limited basic services, and high unemployment. The majority of the respondents $(55.6 \%, n=250)$ were unemployed and survived by engaging in informal activities.

\section{Hopley, the Marginalized Community and Space of Discomfort}

Despite the fact that Hopley is in close proximity to established settlements and bounded by major transport routes (see Fig. 1), the community remains isolated and disconnected from the formal system that serves most parts of Harare. "When the settlement was established in 2005, the City of Harare connected water from existing settlements but these were eventually cut off due to the reduction in pressure on the

\footnotetext{
${ }^{2}$ Interview with resident, January 27, 2018

${ }^{3}$ ZANU-PF is the ruling political party that was then led by the late President Robert Mugabe. The party has retained power since 1980 when Zimbabwe gained independence from British colonial rule.
} 
already existing settlement."4 Another resident commented: "Sometimes the water from the wells is dirty and has a milky white colour which makes it difficult to drink or use for other domestic chores such as doing one's laundry because of its thickness hence we are compelled to source water from the communal boreholes." access to reticulated water in Hopley confirms the characterization of emerging settlements as spaces of exclusion and discomfort (Young 1990; Mtapuri and Myani 2020). The residents largely blame the government for failing to develop Hopley. "We are the less-privileged citizens in Harare. We live here where the government simply dumped us and made no effort to connect us to the reticulated sewer. There is virtually no development in this place." In response to such accusations, an official from the City of Harare explained, "The local authority lacks the financial capacity to finance the infrastructure development for emerging settlements in Harare, and Hopley is not an exception hence the settlement, like many others has remained without services."7 Therefore, the marginalization and exclusion in Hopley reveal the spatial injustice that exists. Despite water and sanitation being human rights, citizens in Hopley are denied access.

Faced with water scarcity, the situation in Hopley confirms the desperate theory as they improvise to access water and other services. Yet, there are sanctions in accessing this water as recounted by a resident, "[...] in most instances we access water from unsafe sources because the communal boreholes are politicized and also one has to pay to get the water, which means those who cannot afford to pay for this water end up resorting to unsafe water from shallow wells." ${ }^{8}$ Hopley also lacks a reticulated sanitation system, which again forces residents to improvise. "Pit latrines are used owing to absence of reticulated sanitation system, but these are not ideal for the emerging settlement which is dense and has small plot sizes". 9 The result is groundwater contamination in Hopley through the proliferation of pit latrines, as confirmed in a study by Ndoziya, Hoko, and Gumindoga (2019). "We use water from the well regardless of its state. I cannot afford to buy or access tap water. Where can I get the money to pay US $\$ 1$ per day for water? But the water is really bad because earlier on my 5 -year-old daughter got really sick and she was passing out stool with blood. She was admitted in hospital for a week and it was dysentery which had infected her."10 Essentially, it costs more for the residents to access water and failure to sacrifice one's money results in risk of contracting diseases, as evident from the foregoing quote.

The discomfort posed by staying in Hopley compels residents to improvise on the use of space. The street is one such component of the settlement's fabric, which has been manipulated by Hopley residents to find comfort. It was observed that the street serves different functions in the everyday life of the residents of Hopley. As Fahlberg et al. (2020) point out, the poor devise strategies that enable them use the space they occupy. Despite the absence of formal services and restricted choices, residents find ways to recreate the space they live in to provide the services that enable them to fulfill

\footnotetext{
$\overline{{ }^{4} \text { Interview with resident, January }} 28,2018$

${ }^{5}$ Interview with resident, January 28, 2018

${ }^{6}$ Interview with resident, January 29, 2018

${ }^{7}$ Interview with official from City of Harare, April 9, 2018

${ }^{8}$ Interview with resident, February 4, 2018

${ }^{9}$ Interview with official from City of Harare, April 4, 2018

${ }^{10}$ Interview with resident, February 4, 2018
} 
some of their daily needs. "Since the authorities have failed to take charge and provide the required services in Hopley, residents have taken matters into their own hands by solving their immediate problems in ways they see as most befitting. This has resulted in some residents in Hopley using the street as a dumping ground for solid waste as well as waste-water which is directed from the "toilets" onto the street."11

Waste disposal is one of the major challenges that exist in Hopley considering that there are no municipal services for waste management. The result is that residents simply dispose waste anywhere they find to be convenient for them (see Fig. 2). A resident pointed out that: "Although some of us dig rubbish pits, the majority of the people around here simply throw the waste on the streets or behind their houses and the waste especially becomes a nuisance when it rains. Also regardless of the rains, the odor from these dumpsites can be a major challenges at times which also attracts flies exposing us to cholera."12 This indicates some form of rebellion, silent protest, and lack of stewardship for the place. In this way, the diversity of the urban space is highlighted as well as the activities that the residents undertake to eke out a living considering how they are disconnected from formal services (Turok 2020).

\section{Right to Space and Belonging (Spatial Injustice)}

Despite having been allocated the plots in 2005, the respondents highlighted that they lacked entitlement to their plots. The lack of entitlement to plots through absence of title deeds, even for residents who were allocated the plots by the City of Harare, is an indication of the strategy of politicians to alienate the residents of Hopley and make sure that they have no claim to the land. As Mtapuri and Myeni (2020) put it across, this is a strategy meant to buttress the vulnerability of the poor and make them to be at the mercy of the government. Chatiza (2013) also concluded that politicians manipulate individuals and communities using urban spaces such as emerging human settlements to enforce intimidation. In Hopley, this was explained in the manner in which local ZANU-PF leaders in the community parceled out plots to landless party "supporters." The official from City of Harare highlighted that, "[...] such stands (plots) are allocated to people on land that has been designated for public amenities such as schools and clinics. Yet, the MDC supporters do not benefit from such land allocations." ${ }^{\prime \prime}$ In this regard, as explained by Mtapuri and Myeni (2020), the choices of the people are determined and controlled by the politicians who disregard official land uses and take matters into their own hands with regard to who resides where in Hopley. The power dynamics at play in Hopley is shown through one's allegiance to ZANU-PF. "If one is not affiliated to the party, or fails to attend meetings, then they are considered to be sellouts. Therefore, everyone is forced to attend the meetings." 14

Spatial injustice is also seen in housing conditions, as Mtapuri and Myeni (2020) argue that desperation manifests through the discomfort communities endure. In Hopley, there are different typologies of housing. While some are conventional, constructed with modern building materials, others are built from makeshift materials

\footnotetext{
${ }^{11}$ Interview with an official from an NGO, February 7, 2018

${ }^{12}$ Interview with resident, February 5, 2018

${ }^{13}$ Interview with official from City of Harare, 9 April 2018

${ }^{14}$ Interview with resident, 29 January 2018
} 


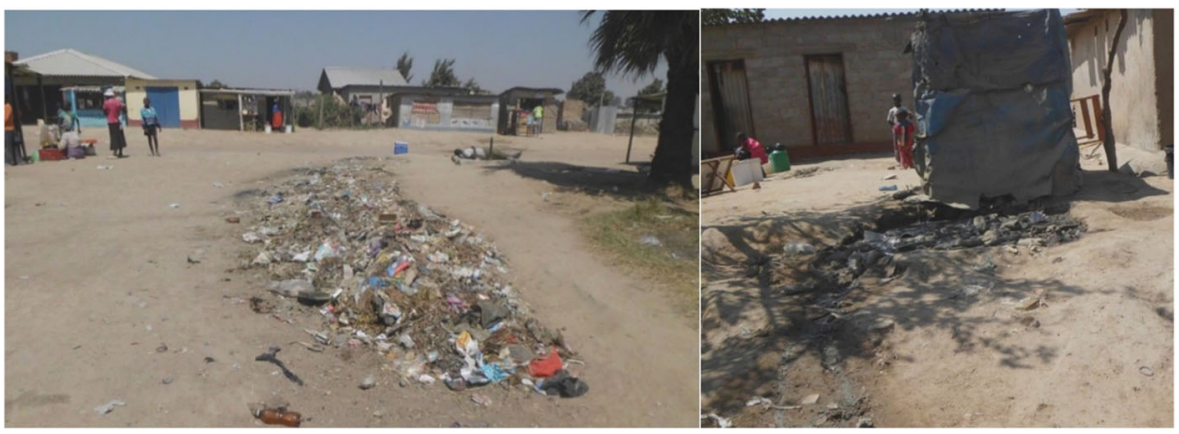

Fig. 2 Solid waste dumped on the street and a woman selling her wares as a man reclines waiting for customers to buy cool drinks. The image on the right shows wastewater flowing in the streets from a "septic tank"

and include black polythene plastics, farm bricks, corrugated iron sheets, and wood (see Fig. 3 and Fig. 4). An official from City of Harare commented that, "The differences in housing typologies are a result of the differences in the manner in which the individuals acquired the plot. This is so because for those who were resettled by the government during OM and the individuals on the council housing waiting list who also got land in this area have an entitlement to the place, regardless of not having title deeds."15 However, the residents highlighted that they were afraid to invest in developing their housing units considering what the government did to the households whom they relocated to Porta Farm. This confirms the argument of Mtapuri and Myeni (2020) who characterize emerging settlements as spaces of exclusion where the poor are confined by authorities. It also explains how authorities use power to oppress citizens and ensure that they remain as what Hall (1996) describes as the "permanent underclass" who live at the mercy of the authorities. The residents are used by politicians to manipulate the electorate while they exercise their power and authority. Furthermore, some residents are new settlers who obtained their right to the land from land barons and unscrupulous ZANU-PF leaders in the community. The open spaces reserved for schools and clinics are subdivided and converted to residential use. "There are different people who live here in Hopley, some of us got our plots from the government during Operation Murambatsvina and I know I am entitled to this land. So I went on to build this house, but for others, especially those who moved in recently, they lack any security because they probably got the land from the land barons who subdivides any open space and sells it to the desperate home seekers for as little as US\$200. Imagine in Harare where do you get land at that price."16

Some of the housing fails to meet the requirements of a decent shelter, which ought to protect its inhabitants from the weather and provide privacy to its occupants. "[...] during rainy season it's not safe the houses are likely to fall..." 17 The comfort and discomfort element postulated by Mtapuri and Myeni (2020) comes into perspective as shown in Fig. 4. The small plot sizes where some residents have developed makeshift housing units of just two rooms, makes it difficult for those with large families, and

\footnotetext{
${ }^{15}$ Interview with official from City of Harare, April 9, 2018

${ }^{16}$ Interview with resident, February 25, 2018

${ }^{17}$ Interview with resident, February 24, 2018
} 


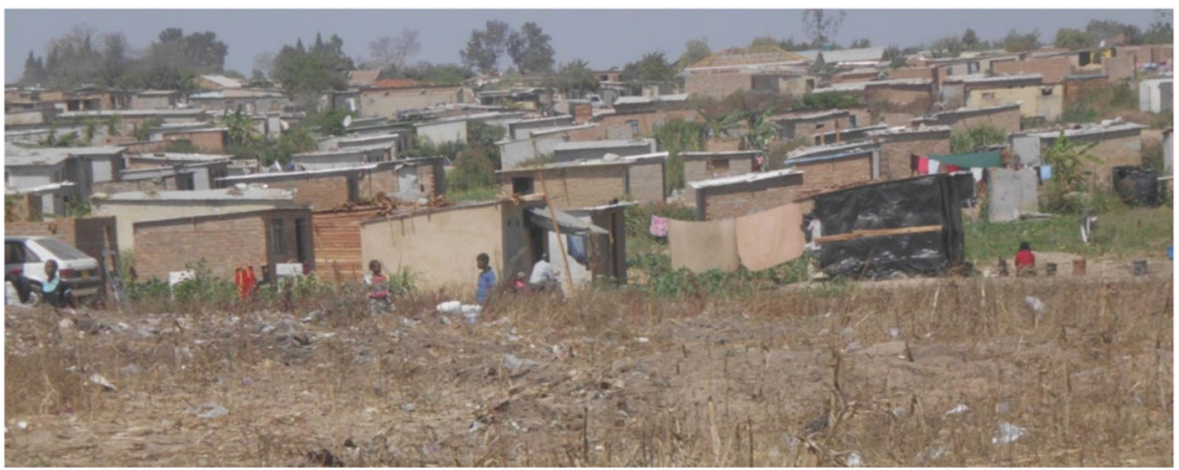

Fig. 3 The diversity of housing structures in Hopley shown in this picture where black polythene plastic is used, alongside a wood cabin, while in the background, conventional materials are used for roofing which is rarely the case

overcrowding is common. For some, a room is shared by $3-4$ women, each having at least one child living in the same room. The overcrowding acts as a breeding ground for infectious diseases such as tuberculosis and influenza. In this instance, privacy is another aspect residents do not have, as one female respondent recounted, "It is tough living under these conditions my brother, but what can one do. At times, you come back home and you are tired, yet your housemate will be entertaining a customer then you cannot budge in. You will simply have to wait or find somewhere else to put up for the night". 18

\section{Poverty and Immorality (Spaces of Oppression and Domination)}

Poverty is rife in Hopley, as shown by the modal monthly family income of US\$50, which translates to a daily income of approximately US\$1.66 or less. This is way below the US\$1.90 per day, which characterizes extreme poverty for citizens in the Global

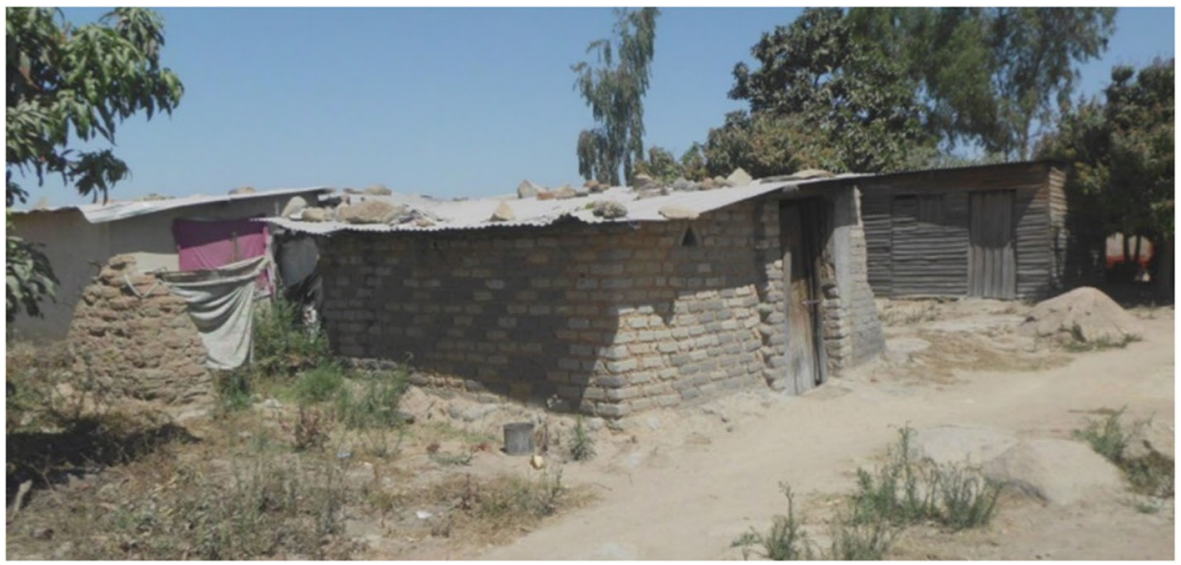

Fig. 4 Housing constructed with sub-standard farm bricks and the walls have been built using mud without cement. The roof is sagging in the middle showing a lack of trusses to support the iron sheets that are held in place by the rocks on top of the structure. In the background is a cabin made from wood that accommodates another family 
South. Poverty levels in Hopley are aggravated by high unemployment levels in the settlements. Findings from the survey show that $20.2 \%(n=91)$ are employed, $55.6 \%$ $(n=250)$ are unemployed, $10 \%(n=45)$ are self-employed, while $14.2 \%(n=64)$ were not comfortable to share their occupation. Upon probing, it was revealed that the majority of those who shied away from disclosing their occupations were mostly sex workers. Overall, most households depend on informal economic activities as evident from the greater proportion of the respondents $(55.6 \%, n=250)$ who explained that they engage in vending as a livelihood strategy.

Due to the high unemployment levels and limited incomes among the residents of Hopley, social vices are rife in this community. "Many people are unemployed around here and men usually resort to drinking and smoking as a past time during the day and as you can see from the various shebeens that are scattered around the settlement where cheap homemade beer is sold."19 The shebeens (informal drinking places) are a nuisance to majority of the residents in Hopley considering what the patrons do when they get drunk. "The shebeens in this neighborhood makes it unsafe. Worse, the noise at night coming from prostitutes and drunkards makes it difficult for me to sleep." ${ }^{20}$ As Mtapuri and Myeni (2020) explain, these are some of the discomforts experienced when staying in such settlements. Aside from the noise, the shebeens were identified as places of social vices, which include drugs and child prostitution. "It not safe in zone 2 because of a nearby shebeens and the majority of children are out of school and they spend time looking for drugs and some of the young girls are becoming sex workers."21 It also emerged that, "There are shebeens in zone 2 which makes it a meeting place for prostitutes and criminals. Some people are coming from other locations to get cheap sex and our children are changed their ways of thinking because of that environment.",22

Evident from the above quotations is the proliferation of prostitution in Hopley and a cause of morale decay among children who are exposed to such practices. To make matters worse, child prostitution is rife in Hopley. The results also indicate the common occurrence of child marriages and teenage pregnancies, which stand at $18 \%$ and $21 \%$ respectively. This was evident from the survey and the in-depth interviews with residents who identified a place called "Antony," which becomes alive at night and where most of the prostitution takes place. It was revealed that children in Hopley are driven into prostitution due to a number of reasons, which include poverty and the need to put food on the table. On the other hand, the daily lives of residents in Hopley is also shaped by social capital through which individuals have come to help each other out through agency in times of need.

\section{Conclusion}

This study opens briefly with the overarching goal of the SDGs that seek "to leave no one behind" with regard to urban development and uses the theory of desperation to

\footnotetext{
$\overline{19}$ Interview with resident, February 25, 2018

${ }^{20}$ Interview with resident, January 18, 2018

${ }^{21}$ Interview with resident, January 20, 2018

${ }^{22}$ Interview with resident, January 18, 2018
} 
explore the daily lives of residents in emerging settlements in Hopley, Harare. Ironically, the case study shows that the Zimbabwean government has done exactly the opposite as evident from the history of exclusion and intimidation where the urban poor have been victims of state orchestrated displacements and evictions. The poor are thus forced to live on the margins of what Mtapuri and Myeni (2020) describe as living in discomfort. Their daily lives are characterized by fear of evictions and uncertainty with regard to making ends meet. Proliferation of poverty, lack of basic services, and unemployment compromise the daily lives of the residents who are forced to improvise on a number of issues to enhance their livability in Hopley. However, in their attempts to make the settlement comfortable, residents in Hopley tend to exacerbate their daily woes. This is evident in the socioeconomic woes that are created by public health risks and social rot. The study used the phenomenological approach to reflect on the daily lives of the urban poor through respondents' narratives, thus revealing their daily experiences characterized by fear and uncertainty. The findings of the study confirm the ideas of this theoretical framing, as it showed how the people of Hopley, especially the poor, have been constructed by the government as the underclass who are denied their right to the city through displacement, dispossession of their land, and exclusion in accessing formal services. This was also asserted by Turok (2020) who showed how the failure of cities to plan, anticipate, and project urban growth, results in oppression, exclusion, and squalor among the poor. Here, the poor undergo problems such as public health and safety risks as well as human rights violations. The poor often live under harsh conditions where their lived experiences remain unknown by policy makers. Hence, this study raises awareness among the authorities on how far the urban poor lag behind and how such inequalities make it difficult for the city and nation at large to achieve the SDGs. In this way, city authorities and the government may then be compelled to take action towards promoting better conditions in Hopley and similar settlements.

Future research in emerging settlements may focus on examining the nexus of citizenship and participation among the urban poor and how it relates with the right to the city with a view to inform urban policy and planning. The results from this study also raise critical questions about how social protection may be strengthened and extended to reach the urban poor such that their daily lives are not characterized by the discomfort resulting from their desperation and makeshift urbanism. The major challenge for government would be to focus on efforts to redistribute basic services to address the inequalities in Harare, which result in the negligent of citizens described in the foregoing discussion. Responsible authorities need to be held accountable for violating human rights, while capacity building may be required to make the community efforts more robust and sustainable instead of exacerbating the current situation.

Acknowledgments The author would like to acknowledge the support from Professor Verna Nel who assisted with review of the initial draft of the paper. The assistance from Mrs. Liesl van der Westhuizen with regard to language editing for the paper is also appreciated. The comments and insights from the editorial team and the two reviewers have also been very valuable to the author.

\section{Compliance With Ethical Standards}

Conflict of Interest The author declares that he has no conflict of interest. 


\section{References}

Amnesty International. (2006). Zimbabwe - No justice for the victims of forced evictions, 8 September. Available at. https://www.refworld.org/docid/451791c14.html [accessed 7 May 2020].

Bafana, B. (2016). Africa's cities of the future: Proper planning key to sustainable cities. Africa Renewal, $30(1), 4-5$.

Creswell, J. W. (2013). Qualitative inquiry and research design: Choosing among five approaches (3rd ed.). London: Sage.

Chatiza, K. (2013). Capacity building/or local government and service delivery in Zimbabwe. Harare: Development Governance Institute.

Chitekwe-Biti, B. (2009). Struggles for urban land by the Zimbabwe Homeless People's Federation. Environment and Urbanization, 21(2), 347-366.

Corburn, J. (2013). Healthy city planning. London: Routledge.

Fahlberg, A., Vicino, T. J., Fernandes, R., \& Potiguara, V. (2020). Confronting chronic shocks: Social resilience in Rio de Janeiro's poor neighborhoods. Cities, 99(2020), 102623. https://doi.org/10.1016/j. cities.2020.102623.

Fainstein, S. S. (2014). The just city. International Journal of the Unity of the Sciences, 18, 1-18.

Green, N., \& Handley, J. (2009). Patterns of settlement compared. In: Davoudi, S, Crawford, J and Mehmood, A, Planning for climate change: Strategies for mitigation and adaptation for spatial planners. London: Earthscan.

Hall, P. (1996). Cities of tomorrow: An intellectual history of urban planning and design in the twentieth century. (eds.). Oxford: Blackwell Publishers.

Harvey, D. (2012). Rebel cities: From the right to the city to the urban revolution. London: Verso.

Huchzermeyer, M. (2011). Cities with 'slums': From informal settlement eradication to the right to the city in Africa. Cape Town: UCT Press.

Johari, S. J. (2019). What if the poor were part of city planning? TedWoman Talk. https://www.ted. com/talks/smruti jukur johari what if the poor were part of city planning?language=en\#t-791348

Krejcie, R. V., \& Morgan, D. W. (1970). Determining sample size for research activities. Educational and Psychological Measurement, 30, 607-610.

Lall, S. V., Henderson, J. V., \& Venables, A. J. (2017). Africa's cities: Opening doors to the world. Washington, DC: World Bank.

LeVan, C. A., \& Olubowale, J. (2014). 'I am here until development comes': Displacement, demolitions, and property rights in urbanizing Nigeria. African Affairs, 113(452), 387-408.

Moroni, S. (2019). The just city. Three background issues: Institutional justice and spatial justice, social justice and distributive justice, concept of justice and conceptions of justice. Planning Theory, 0(0), 1-17.

Mphambukeli, T. N. (2019). Social justice in planning: Access to adequate drinking water and contested belonging in emerging communities of Mangaung in post-apartheid South Africa. African Renaissance, Special Issue, August, 2019, 51-69.

Mtapuri, O., \& Myeni, S. L. (2020). Sustainable development goals and the new urban agenda: A South African experience. In Myeni, S. L and Okem, A. E (eds.), The political economy of government subsidized housing in South Africa (pp. 12-27). New York: Routledge.

Ndoziya, A. T., Hoko, Z., \& Gumindoga, W. (2019). Assessment of the impact of pit latrines on groundwater contamination in Hopley Settlement, Harare, Zimbabwe. Journal of Water, Sanitation and Hygiene for Development, 09(3), 464-476.

Obasanjo, O., Pinzó, J. C., Mills, G., Hartley, R., Hamukoma, N., et al. (2020). Future of African cities project. Special report - January 2020. Where the rubber hits the road. Johannesburg: The Brenthurst Foundation.

Olajide, V. (2019). Data management and data analysis (Data collection: KoboToolbox). Available at: file:/// C:/Users/2016104669/Downloads/data collection KoboToolbox.pdf

Patel, D. (1988). Government policy and squatter settlements in Harare, Zimbabwe. In, Obubho, R. a and Mhlanga, C. C., Slum and squatter settlement in sub-Saharan Africa: Towards a planning strategy. New York: Praeger publishers, p. 205-218.

Philippopoulos-Mihalopoulos, A. (2010). Law's spatial turn: Geography, justice and a certain fear of space. Law, Culture and the Humanities, 7(2), 187-202.

Potts, D. (2007). City life in Zimbabwe at a time of fear and loathing: Urban planning, urban poverty and Operation Murambatsvina. In G. Myers \& M. Murray (Eds.), Cities in contemporary Africa (pp. 265288). New York: Palgrave Macmillan.

The Herald. (2001). Harare to demolish illegal outbuildings, over 500000 to be made homeless, March 10. 
Turok, I. (2020). Delhi's public health crisis and the neglect of urbanisation. Local Economy, 35(1), 3-6.

United Nations. (2016). Leaving no one behind: The imperative of inclusive development. Report on the world social situation 2016. Washington, D. C: United Nations.

Wanjiru, M. W., \& Matsubara, K. (2017). Slum toponymy in Nairobi, Kenya: A case study analysis of Kibera, Mathare and Mukuru. Urban and Regional Planning Review, 4, 21-44.

Yiftachel, O. (2009). Critical theory and 'gray spaces': Mobilization of the colonized. City, 13(2-3), 241-256. Young, I. M. (1990). Five faces of oppression. Justice and the politics of difference. Princeton, NJ: Princeton University Press.

Zinyama, L., Tevera, D., \& Cumming, S. (1993). Harare: The growth and problems of the city. Harare: University of Zimbabwe Press.

Publisher's Note Springer Nature remains neutral with regard to jurisdictional claims in published maps and institutional affiliations. 